\title{
The Impact of Institutional Investors on Firms Accounting Flexibility: Evidence from Jordan
}

\author{
Imad Z. Ramadan \\ Correspondence: Finance and Banking Science Department, Applied Science Private University, P.O. Box 166, \\ Postal Code 11931, Amman, Jordan. Tel: 962-79-6177-911. E-mail: Prof_imad67@asu.edu.jo
}

Received: March 13, 2012

doi:10.5539/ijef.v4n6p141

\author{
Accepted: April 6, 2012 \\ Published: June 1, 2012 \\ URL: http://dx.doi.org/10.5539/ijef.v4n6p141
}

\begin{abstract}
In this paper the existence of the impact of the institutional investor on the firm's accounting flexibility in generating discretionary accruals was verified. For this purpose balanced data cross-sectional regression model for all $70^{\mathrm{th}}$ Jordanian manufacturing companies listed at Amman Stock Exchange (ASE) over eleven years from 2000 to 2010 was utilized. In the regression model discretionary working capital accruals (DWCA), proxy for earnings manipulation, was set as the dependant variable. Independent variables were; the percentage of the institutional investors ownership of common stock in firm as a proxy of the institutional investors (IIP), the managerial ownership (MAO), firm's size (SIZE), leverage ratio (LEV), and return on sales ratio (ROS). The econometric model was estimated. The results of various analysis and tests carried out in this study confirm the monitoring role of the institutional investors and the role played by the institutional investor in alleviating the practices of earnings management.
\end{abstract}

Keywords: institutional investors, accounting flexibility, Jordan

\section{Introduction}

This paper seeks to investigate the effect of institutional ownerships on earnings manipulation activities in the Jordanian industrial firms. To achieve this aim, the possibility of association between institutional investors and accounting flexibility available to firms to generate discretionary accrual was investigated. The importance of this study is its attempt to cover a lack of studies on the impact of one component of corporate governance on managing earnings practices in developing countries such as Jordan.

Many previous studies concluded that the earnings management is a familiar practice in companies (e.g. Miglo, 2007; Bissessur, 2008). It is a well known fact managers use their authority in choosing accounting methods in order to maximize their own benefits. Most of the studies that addressed the earnings management focused on the goals that drive managers to manage earnings and methods of earnings management, and most of the time ignored company-specific characteristics that affect the ability of this company to manage earnings assuming constant ability across companies. Few studies have investigated the effect of company-specific characteristics in their ability to practice earnings manipulation (e.g., Francis et al., 1999; Klein, 2002; and Chung et al., 2002).

Regardless of whether they do so or not, institutional ownerships have the ability, potential, and motivation to monitor managers in order to reduce their ability to achieve their own benefits against the shareholder's. This study examine the impact of institutional ownerships on company's ability to generate discretionary accruals in the existence of a set of control variables, which previous studies have confirmed it's significantly impact on earnings management practices, namely: managerial ownership, size, leverage, and profitability.

Using balanced panel data for all $70^{\text {th }}$ Jordanian manufacturing firms listed at ASE, between the years 2000 to 2010, the study estimated the discretionary working capital accruals, proxy for the firm's accounting flexibility available, using the Jones (1991) model. The model of the study was estimated using the regression-based framework Pooled Ordinary Least Square Method (OLS). And a set of tests and analysis were conducted namely: descriptive analysis, univariate test of mean difference, correlation analysis, and regression analysis.

The findings of this study indicate a strong evidence for the impacts of the institutional ownerships on the managing earnings practice. Institutional investors found to be capable to reduce the managers' tendency towards the exercise of managing earnings. This result corresponds with the fact that institutional ownership has a surveillance role over the managers, and in order to reduce the agency problem, institutional investors have to exercise this role efficiently and effectively. 


\section{Related Literature}

In their study Lin, L. and Manowan, P. (2011) investigate the institutional investor's effect on earnings manipulation, they differentiate between two scenarios of earnings management: decreasing and increasing income, as for decreasing income through earnings management they did not find any statistically significant impact of the institutional ownerships on the earnings management, this is the inevitable result of the difference in institutional ownerships time horizon and nature. To overcome this hurdle, the researchers classified the institutional investors according to their nature to: transient investors (investors who owned diversified and high turnover portfolios), and dedicated investors (investors who owned concentrated and low turnover portfolios). Based upon, the study concluded a direct statistically significant correlation among transient investors and managing earnings, and an inverse relationship but not statistically significant among the dedicated investors and earnings manipulation. The study also concluded that because of the difference in institutional investor nature, we cannot treat them as a homogeneous group.

Rebai, I. (2011) investigated the impact of the institutional investors on managing earnings for 123 American firms. He concluded that, while transient investors (investment funds) inspire managers to spend less on R\&D, Bank Holding Company and long-term institutional investors (pension funds) are passive.

Mitra S. (2002) investigates the ability of the institutional investor to limit the practice of companies to manage earnings. The study examines the relation between the flexibility available to firms in generating discretionary working capital accruals and institutional investors. The study concluded that institutional investors reduce significantly the ability of the manager's flexibility in generating discretionary working capital accruals, and the concentrated institutional ownership reduces the tendency of the management towards managing earnings. Moreover, while the study found that the institutional investors do not have the ability to reduce the earnings management practices in S\&P 500 firms; they have significant ability to reduce earnings manipulation activities in other companies.

Bushee (1998) studied the role of institutional investor in mitigating the managerial tendency towards abandoning long-term investments in order to achieve current earnings target. The study concluded that firms are not expected to manage earnings with existence of high percentage of institutional investors, which refers to the monitoring role played by institutional investors compared to individual investors. The study also concludes that the existence of high percentage of transient institutional investors leads to the possibility of increasing the practice of earnings management by reducing spending on $\mathrm{R} \& \mathrm{D}$ in order to increase profits. Based upon, the study indicated that the presence of high percentage of transient institutional investors in the firm leads to myopic investment behavior resulting in the sacrifice of long-term investments in order to meet the current target profit.

\section{Methodology}

\subsection{Data}

Variables utilized in the study, definition, and measures are presents at Table 1 . The study employed econometric analysis using balanced panel data regression of all $70^{\text {th }}$ Jordanian manufacturing companies listed at ASE for the period 2000-2010 resulting in 770 firms' year observations. The data for the firms in the sample were derived from the ASE. For the econometric analysis, the study adopted the discretionary working capital accruals $(D W C A)$, a proxy for the accounting flexibility in generating accruals. Independent variable of interest is the institutional investor (IIP) measured by dividing institutional ownerships of common stock over total common stock. Based on previous studies, four variables that have effect on the availability of accounting flexibility in generating discretionary accruals were adopted as a control variables namely: managerial ownership (MAO), firms size (SIZE), leverage $(L E V)$, profitability $(R O S)$. 
Table 1. Variables definition

\begin{tabular}{|c|c|c|c|c|}
\hline & Variable & Measure & Notation & $\begin{array}{l}\text { Expected } \\
\text { Effect }\end{array}$ \\
\hline $\begin{array}{l}\text { Dependent } \\
\text { Variable }\end{array}$ & $\begin{array}{l}\text { Accounting Flexibility } \\
\text { (earnings Management) }\end{array}$ & $\begin{array}{l}\text { Discretionary working capital accruals defined as the deference } \\
\text { between the total working capital accruals and the non-discretionary } \\
\text { working capital accruals. }\end{array}$ & $D W C A$ & \\
\hline $\begin{array}{l}\text { Independent } \\
\text { Variable of interest }\end{array}$ & Institutional Investors & $\begin{array}{l}\text { Ratio of institutional ownerships of common stock to total common } \\
\text { stock. }\end{array}$ & $I P P$ & $?$ \\
\hline \multirow[t]{4}{*}{ Control Variable } & Managerial ownership & Equity shares percentage owned by the managers. & MAO & - \\
\hline & Firm's size & Logarithm of the total assets. & SIZE & - \\
\hline & Leverage ratio & The ratio of total liabilities to total assets. & $L E V$ & + \\
\hline & Profitability & Income before interest and tax divided by the annual net sales & $R O S$ & - \\
\hline
\end{tabular}

\subsection{Variables}

\subsubsection{Dependent Variable}

In the regression model discretionary working capital accruals ( $D W C A)$, proxy for earnings manipulation, was set as the dependant variable, measured by subtracting non-discretionary current accruals from total current accruals.

Following Jones (1991), total current accruals defined as the interaction of changes in sales minus changes in account receivables, plus plant, equipment and property, therefore, the following model were estimated:

$$
T W C A_{i t}=\alpha+\beta_{1}\left(\Delta S_{i t}-\triangle A R_{i t}\right)+\beta_{2} P P E_{i t}+\varepsilon_{i t}
$$

$T W C A$ : total working capital accruals, $i$ : firm $i, t$ : time $t, \Delta$ : annual change, $S$ : annual sales, AR: account receivable, $P P E$ : gross property.

To reduce the potential for heteroscedasticity the variable in equation (1) has been scaled by the total assets. The following equation has been estimated:

$$
\frac{T W C A_{i t}}{T A_{i, t-1}}=\alpha \frac{1}{T A_{i, t-1}}+\beta_{1}\left(\frac{\Delta S_{i t}-\Delta A R_{i t}}{T A_{i, t-1}}\right)+\beta_{2}\left(\frac{P P E_{i t}}{T A_{i, t-1}}\right)+\varepsilon_{i t}
$$

Where $T A_{i, t-1}$ is the total assets.

Equation 2 is computed separately for each sample company, and DWCA is computed from the residuals of these regressions, using the coefficients estimated in equation 2 , the non-discretionary component of working capital accruals has been removed. Thus the remaining accruals, discretionary working capital accruals ( $D W C A)$, are due to earnings management, so the following equation has been estimated:

$$
\mathrm{DWCA}_{\mathrm{it}}=\frac{\mathrm{TWCA}_{\mathrm{it}}}{\mathrm{TA}_{\mathrm{i}, \mathrm{t}-1}}-\hat{\alpha}\left(\frac{1}{\mathrm{TA}_{\mathrm{i}, \mathrm{t}-1}}\right)+\hat{\beta}_{1}\left(\frac{\Delta \mathrm{S}_{\mathrm{it}}-\Delta \mathrm{AR}_{\mathrm{it}}}{\mathrm{TA} \mathrm{A}_{\mathrm{i}, \mathrm{t}-1}}\right)+\hat{\beta}_{2}\left(\frac{P P E_{i t}}{T A_{i, t-1}}\right)+\varepsilon_{i t}
$$

DWCA $_{i t}$ : Discretionary working capital accrual, $\quad \hat{\alpha}, \quad \hat{\beta}_{1}$ and $\hat{\beta}_{2}$ are coefficient estimated in equation (2).

\subsubsection{Independent Variable of Interest}

Independent variable of interest is the institutional investor (IIP). Previous studies on the impact of institutional investor on the companies concluded mixed results. Bushee, B.J. (1998) concluded that high percentage institutional investors firms tend to spend more on the R\&D. However, if the institutional investor in the firm is engage in momentum trading, the possibility of the firm to reduce its spending on R\&D increase to increase the profitability of the firm. Bange and Bondt (1998) concluded that increase company profits by reducing spending on R\&D is less likely to occur with high percentage of IIP. Due to the fact that institutional investors spend more on information search, Shiller and Pound (1989) and Lev (1988) concluded that there is an inverse relationship between the aggressive practicing of earnings management by the managers and the percentage of institutional investors in the company.

In terms of institutional investor influence on the performance of the company, mixed results were documented, Smith M. (1996) concluded a direct correlation between the firm's performance and institutional investors, while Duggal and Millar (1999), Facio and Lasfer (2000) and Mizuno M. (2010) did not support this result, and concluded no statistical evidence that IIP influence the performance of the companies. 


\subsubsection{Control Variable}

Four control variables with significant impact on earnings management practices were adopted, these variables are:

\subsubsection{Managerial Ownership}

Managerial ownership $(M A O)$ is defined as the equity shares percentage owned by the managers. Previous studies have confirms the managerial ownerships managing earnings relationship (hence, the availability of the accounting flexibility). Warfield et al., (1995) found that as the managerial ownership increases, the possibility of earnings management decreases, because, the higher the managerial ownership percentage is, the higher is the conformity and harmony of interest between managers and shareholders, and the higher is the managerial reliability on long-term value of firms rather than short-term profit.

Managerial ownership was adopted in the model study to take into consideration the tendency of the managers to generate accruals in the presence of the institutional ownerships, and is expected to have negative impact on the firm's accounting flexibility.

\subsubsection{Firm Size}

In their study Kim, Y. et. al., (2003) concluded that the impact of firm's size on the managing earnings is different : while small firms are more than large firms engaging in earnings management to avoid disclosure of losses, larger firms are more violent in managing earnings than small firms to avoid reporting decreases in the earnings.

Size (SIZE), defined as the firm's total asset logarithm is expected to associate negatively with the firm's accounting flexibility.

\subsubsection{Leverage}

Leverage ( $L E V$ ), measured by dividing total liabilities over total assets, measures the risks of the company's ability to fulfill its obligations. The higher the debt ratio, the closer the firm is to violate its debt obligation. Defond and Jiambalvo (1994) found that as the firm approachs debt-covenant violation, the possibility of engaging in earnings management increases to avoid or delay the violation. Also, Duke and Hunt (1990) concluded a direct correlation between debt ratio and inability to fulfill debt obligation. Therefore, a direct relationship between the leverage and the firms accounting flexibility available to generate discretionary accruals is expected.

\subsubsection{Profitability}

McNichols (2000) documented that including a variable of profitability in the multiple regression model increases the explanatory power of explaining the changes in the discretionary accruals, indicating that more profit firms are directly correlated with positive discretionary accruals.

Profitability (ROS), defined as the earnings before interest and tax divided by the annual sales, is adopted to control the effect of stockpiling inventory rise as a result of unusual business operations.

\subsection{Estimation Model}

To test the potential impact of IIP on CWCA, the study employed a cross-sectional regression technique. The linear regression model can be estimated as follows:

$$
D W A C_{i t}=\alpha+\beta_{1} I I P_{i t}+\beta_{2} M A O_{i t}+\beta_{3} S I Z E_{i t}+\beta_{4} L E V_{i t}+\beta_{5} R O S_{i t}+\varepsilon_{i t}
$$

Where; $D A W C$ is the discretionary working capital accruals, as a proxy of the firm's accounting flexibility in generating discretionary accruals for $i^{\text {th }}$ cross-sectional firm for the $t^{\text {th }}$ time period, with $i=1,2,3, \ldots, 70, t=$ $1,2,3, \ldots, 11, \alpha$ is constant, $\beta$ 's are unknown parameters of the firm's characteristics included in the model to be estimated, IIP is the institutional investors defined as ratio of institutional ownerships of common stock to total common stock; $M A O$ is the managerial ownership defined as the common stock percentage owned by the managers; SIZE is the firm's sizes defined as the firm's total asset logarithm; $L E V$ is the leverage ratio defined as the ratio of total liabilities to total assets, ROS is the profitability measure defined as the income before interest and tax divided by the annual net sales, and $\varepsilon$ is the error term.

The next step is to split the firms based on the median of the institutional investor's sample firms, and conduct the univariate test of mean difference to evaluate the potential impact of institutional ownerships on the extent of earnings management practices.

Based on previous studies, the effect of institutional ownerships on the accounting flexibility is expected to be adversely. Since the firms accounting flexibility to generate discretionary accruals is directly significantly correlated with the extent of earnings management, the study predicts inverse correlation between the institutional ownerships and the firm's accounting flexibility of generating discretionary accruals. 


\section{Empirical Results}

\subsection{Descriptive Analysis}

Table 2 presents the results of the descriptive analysis for the variables employed in the study. Results shows that the mean and median of the DWCA, are $4.28 \%$ and $3.3367 \%$ respectively, with a distribution range of Min. of $2.91 \%$ and a Max. of $58.28 \%$.

The average institutional investor ownership in Jordanian industrial companies is $19.95 \%$, while the average manager's ownership in Jordanian industrial companies is $9.53 \%$. This indicates that, because the institutional investors own twice more than managers (19.95\% versus $9.53 \%)$ institutional investors have a better chance to influence the tendency of exercising earnings management.

Results also shows that the institutional ownership range is wide with a Min. of $0.14 \%$ and a Max. of $68.30 \%$, which leads to increase the reliability of the statistical tests. Also, the distribution of manager's ownership is wide with a Min. of $0.00 \%$ and a Max. of $49.28 \%$.

Table 2. Descriptive analysis results

\begin{tabular}{llllll}
\hline Variables & Mean & Median & St. Dev & Min & Max \\
\hline DWAC & .0428 & .03367 & .04368 & .00291 & .5828 \\
IIP & .1995 & .2150 & .0809 & .0014 & .6830 \\
MAO & .0953 & .0577 & .1087 & .000 & .4928 \\
SIZE & 5194.24 & 1130.22 & 18938.92 & 3822 & 212312.1 \\
LEV & .1858 & .1760 & .1153 & .000 & .7378 \\
ROS & .0883 & .0822 & .0898 & -.6612 & .5931 \\
\hline
\end{tabular}

Definition of the variables presents at Table 1

\subsection{Univariate Test of Mean Difference}

Discretionary working capital accruals were splits based on the median of the institutional investor's variable. Table 3 shows the descriptive analysis of the two groups. As expected, for firms with IIP less than the sample median, the DWCA mean and median were $4 \%$ and $3.03 \%$ respectively, with IIP mean and median of $13.36 \%$ and $13.97 \%$ respectively, on the other hand, firms with $I I P$ greater than the median sample firms, the DWCA mean and median were $3.12 \%$ and $2.85 \%$ respectively with $I I P$ mean and median of $39.6 \%$ and $40.78 \%$ respectively.

Univariate tests showed that the difference in the mean for the IIP variable between firms with IIP less than the sample median and firms with IIP greater than the sample median is significant ( $t$-value $=-144.22, p$-value $=0.000)$. Tests also showe that the $D W C A$ mean's is greater for firms with IIP less than the sample median than firms with IIP greater than the sample median $(t$-value $=269.01 ; p$-value $=0.000)$.

Univariate test results confirm the effectiveness of the monitoring role for institutional investors in reducing the tendency of the managers to practice earnings management, and thereby reduce the accounting flexibility available to the managers to generate discretionary working capital accruals. 
Table 3. Distribution of discretionary working capital accruals based on the median of the institutional investor's variable

\begin{tabular}{lll}
\hline Group & IIP & DWCA \\
\hline Less than the median institutional investors & & \\
Mean & & \\
Median & .1336 & .0400 \\
St. Dev. & .1397 & .0303 \\
Minimum & .1440 & .0428 \\
Maximum & .0014 & .0029 \\
No. & .4155 & .4844 \\
& 385 & 385 \\
More than the median institutional investors & & \\
& & \\
Mean & & \\
Median & .3960 & .0312 \\
St. Dev. & .4078 & .0285 \\
Minimum & .1083 & .0159 \\
Maximum & .4594 & .0011 \\
No. & .6830 & .5828 \\
& 385 & 385 \\
Test of difference in the mean & & \\
t & & \\
p - value & -144.22 & 269.01 \\
Definition of the variables presents at Table 1 & 0.000 & 0.000 \\
\hline
\end{tabular}

\subsection{Correlation Analysis}

Table 4 presents the correlation matrix between the regression's model utilized variables. The results show that IPP is significantly negatively correlated with $D W C A$, indicating that the greater the $I I P$, the lower the availability of the accounting flexibility. This result confirms the Univariate test and the descriptive analysis results mentioned earlier. The IIP is also significantly negatively correlated with $M A O$, which corresponds to the view that the institutions are reluctant to invest in firms that are dominated by the managers. Moreover, the IIP is found to be directly correlated to SIZE and ROS, verifying the role of the institutional ownerships in improving firm's performance. SIZE found to be negatively correlated with $D W C A$, meaning that the availability of accounting flexibility to manage earnings is lower in large firms.

The correlation results also show that the $D W C A$ is significantly positively correlated with $L E V$ indicating that the managers practice earnings management increases the ability of the firm to raise funds. Further, the results did not provide any significant evidence to support the relation between the DWCA and ROS.

Table 4. Correlation Matrix

\begin{tabular}{|c|c|c|c|c|c|c|}
\hline Variables & DWCA & IIP & MAO & SIZE & LEV & ROS \\
\hline DWCA & 1 & & & & & \\
\hline \multirow[t]{2}{*}{ IIP } & -0.1656 & 1 & & & & \\
\hline & 0.000 & & & & & \\
\hline \multirow[t]{2}{*}{ MAO } & -0.0784 & -0.2424 & 1 & & & \\
\hline & 0.063 & 0.002 & & & & \\
\hline \multirow[t]{2}{*}{ SIZE } & -0.1688 & 0.2168 & -0.1936 & 1 & & \\
\hline & 0.000 & 0.001 & 0.002 & & & \\
\hline \multirow[t]{2}{*}{ LEV } & 0.0904 & -0.0528 & 0.0832 & 0.0528 & 1 & \\
\hline & 0.041 & 0.271 & 0.039 & 0.117 & & \\
\hline \multirow[t]{2}{*}{ ROS } & -0.028 & 0.1024 & -0.0240 & 0.1128 & -0.0976 & 1 \\
\hline & 0.154 & 0.032 & 0.217 & 0.023 & 0.009 & \\
\hline
\end{tabular}




\subsection{Regression Analysis}

The regression analysis is present in table 5. Two regression models were analyzed. In Model 1, control variables were excluded, and IIP found to inversely associate with $D W C A$ at less than 0.01 significant level. Moreover, results shows that the IIP was able to explain $5 \%$ of the change in DWCA $\left(\mathrm{R}^{2}=0.051\right)$. In Model 2 , the impact of institutional investors (IIP) on the firms accounting flexibility to generate discretionary working capital accruals $(D W C A)$ were examined with the existence of the control variables. Even after the entering all control variables to the multiple regression model, the regression coefficient of $I I P$ remain statistically significant with the negative sign (coeff: - 4.087, p-value: 0.009). All control variables were statistically significant and as expected, with the exception of ROS. Overall, the results of regression analysis support the inverse correlation between the institutional investors and the firms accounting flexibility in generating discretionary working capital accruals.

Table 5. Cross-Sectional Regressions

\begin{tabular}{|c|c|c|c|c|c|c|}
\hline \multirow[b]{2}{*}{ Variable } & \multicolumn{3}{|c|}{ Model-1 } & \multicolumn{3}{|c|}{ Model-2 } \\
\hline & $\beta$ & $\mathrm{t}$ - value & $\mathrm{p}$ - value & $\beta$ & $\mathrm{t}$ - value & p - value \\
\hline Intercept & .1039 & 8.6118 & 0.000 & .1275 & 9.767 & 0.000 \\
\hline IIP & -.2339 & -4.6540 & 0.003 & -.1755 & -4.087 & 0.009 \\
\hline MAO & & & & -.0936 & -2.811 & 0.037 \\
\hline SIZE & & & & -.2632 & -5.171 & 0.002 \\
\hline LEV & & & & .1275 & 2.555 & 0.043 \\
\hline ROS & & & & -.0479 & -.9547 & 0.376 \\
\hline Regression & & & & 5 & & \\
\hline Residual & & & & 765 & & \\
\hline Total & & & & 769 & & \\
\hline R-Square & .051 & & & .143 & & \\
\hline Adjusted $\mathrm{R}^{2}$ & .0497 & & & .1373 & & \\
\hline F-value & 41.272 & & & 25.469 & & \\
\hline $\mathrm{p}$-value & 0.000 & & & 0.000 & & \\
\hline $\mathrm{N}$. & 770 & & & 770 & & \\
\hline
\end{tabular}

\section{Conclusion}

This paper aimed to investigate the potential impact of the institutional investors on the ability of the firms to practice earnings management as proxy for the availability of accounting flexibility to generate discretionary working capital accruals over eleven years from 2000 to 2010 for all $70^{\text {th }}$ Jordanian manufacturing companies listed at $A S E$.

Depending on the results of various analysis and tests carried out in this study, the study found statistically significant evidence that institutional ownership have an important monitoring role over the Jordanian manufacturing companies, leading managers to reduce the tendency towards the exercise of earnings management, and thus lessen the accounting flexibility.

\section{References}

Bange, M., \& De Bondt, W. (1998). R\&D budgets and corporate earnings targets. Journal of Corporate Finance, 4 , 153-184. http://dx.doi.org/10.1016/S0929-1199(98)00006-6.

Bissersur, S. W. (2008). Earnings quality and earnings management: the role of accounting accruals. Rozenberg Publishers. $\mathrm{http}: / /$ books.google.jo/books?hl=en\&lr=\&id=6E_BFdCioxQC\&oi=fnd\&pg=PA1\&dq=bissessur+s.w+earnings + quality+and+earnings+management.

Bushee, B. J. (1998). The influence of institutional investors on myopic R\&D investment behavior. The Accounting Review, 3, 305-333.

Chung, R., Firth, M., \& Kim, J-B. (2002). Institutional monitoring and opportunistic earnings management. Journal 
of Corporate Finance, 8, 29-48. http://dx.doi.org/10.1016/S0929-1199(01)00039-6.

DeFond, M. L., \& Jiambalvo, J. (1994). Debt covenant violation and manipulation of accruals. Journal of Accounting and Economics, 17, 145-176. http://dx.doi.org/10.1016/0165-4101(94)90008-6.

Duggal, R., \& Millar, J. A. (1999). Institutional ownership and firm performance: The case for bidder returns. Journal of Corporate Finance, 5, 103-117. http://dx.doi.org/10.1016/S0929-1199(98)00018-2.

Duke, J. C., \& Hunt H. G. (1990). An empirical examination of debt covenant restrictions and accounting-related debt proxies. Journal of Accounting and Economics, 45-63. http://dx.doi.org/10.1016/0165-4101(90)90041-2.

Facio, M., \& M. A. Lasfer. (2000). Do occupational pension funds monitor companies in which they hold large stakes? Journal of Corporate Finance, 6, 71-110. http://dx.doi.org/10.1016/S0929-1199(99)00016-4.

Francis, J. R., Maydew, E. L., \& Sparks, H. C. (1999). The role of Big 6 auditors in the credible reporting of accruals, Auditing. A Journal of Practice and Theory, 18(2), 17-34.

Jones, J. J. (1991). Earnings management during import relief investigations. Accounting Review, 29, 193-228

Kim, Y., Liu, C., \& Rhee, S. (2003). The Relation of Earnings Management to Firm Size, Available at: http://www2.hawaii.edu/ fima/Working_Papers/2003_papers/WP03-02.pdf.

Klein, A. (2002). Audit committee, board of director characteristic, and earnings management. Journal of Accounting and Economics, 33, 375-400. http://dx.doi.org/10.1016/S0165-4101(02)00059-9.

Lev, B. (1988). Toward a theory of equitable and efficient accounting policy. The Accounting Review, 63, 1-21.

Lin, L., \& Manowan, P. (2011). Instititional Ownership Composition and Earnings Management, Available At: http://centerforpbbefr.rutgers.edu/2011PBFEAM/Download/AS/AS-22/2011PBFEAM-072.pdf.

Miglo, A. (2007). Can Earnings Manipulation Create Value? Working Paper. Available at: http://papers.ssrn.com/sol3/papers.cfm?abstract_id=1107286.

Mitra, S. (2002). The Impact of Institutional Stock Ownership on A firm's Earnings Management Practice: An Empirical Investigation, Louisiana State University. Available at: http://etd.lsu.edu/docs/available/etd-1028102 142230/unrestricted/Mitra_dis.pdf.

Mizuno M. (2010). Institutional Investors, Corporate Governance and Firm Performance in Japan. Pacific Economic Review, 15(5), 653-665. http://dx.doi.org/10.1111/j.1468-0106.2010.00521.x

Rebai, I. (2011). Institutional Investores Heterogeneity And Earnings Management: The R\&D Investment Strategy. International Journal of Business Research and Management (IJBRM), 1(3), 122-131.

Shiller, R. J., \& Pound, J. (1989). Survey evidence on diffusion of interest and information among investors. Journal of Economic Behavior and Organizations (August), 44-66.

Smith, M. P. (1996). Shareholder activism by institutional investors: evidence from CALPERS. Journal of Finance, 51, 227-252. http://dx.doi.org/10.2307/2329308.

Warfield, T. D., Wild, J. J., \& Kenneth, W. L. (1995). Managerial ownership, accounting choices, and in formativeness of earnings. Journal of Accounting and Economics, 20, 61-91. http://dx.doi.org/10.1016/0165-4101(94)00393-J. 